structure, so such changes are more likely to be adaptive. He deduces that "the evolution of 'new genes' is not the explanation for the origin of diversity of most animal groups". Rather, "it is the switches that encode instructions unique to individual species and that enable different animals to be made using essentially the same tool kit," he says. "Evolution of form is very much a matter of teaching very old genes new tricks!"

But recent data cast doubt on this argument. Humans have about 32,000 protein-coding genes, fruitflies only 13,000 . Clearly, the difference between these species involves the origin of new proteins: in fact, between $40 \%$ and $50 \%$ of our protein-coding genes have no known homologues in flies. So one could argue that the evolution of form is very much a matter of teaching old genes to make new genes. And, given the data, this cannot be difficult.

There are several ways that protein structure can evolve without injurious side effects. One of the most common is gene duplication. Extra copies of a gene can arise by unequal crossing over or by reverse transcription, allowing one copy to retain its function while the other assumes a new function. This process has been a major force in evolution. A large fraction of genes (at least 39\% in humans) are members of families derived from repeated duplications and diversification of ancestral genes, a process that has yielded many evolutionary novelties. These families include the globins (such as myoglobin and the various haemoglobins); immunoglobulins; opsins (which led to colour vision in Old World primates); and olfactory receptors (almost certainly involved in the evolution of a keen sense of smell in land animals). Lactalbumin, which helps to produce milk in mammals, resulted from a duplication of lysozyme, and the crystallins of our eye lenses are ultimately derived from heat-shock genes.

This 'multiply and diversify' model of molecular evolution does not depend solely on the duplication of individual genes; the evolution of tetrapods apparently involved at least two bouts of whole-genome duplication. Many evolutionists agree with the geneticist Wen-Hsiung Li's conclusion that "there is now ample evidence that gene duplication is the most important mechanism for generating new genes and new biochemical processes that have facilitated the evolution of complex organisms from primitive ones". Carroll, however, seems too enamoured of his 'regulation is all' thesis to consider this alternative view.

There are other ways beside gene duplication that proteins have evolved adaptively. These include gene conversion, recruitment of genes to new functions (responsible for creating the antifreeze glycoproteins that allow fish to live in frigid waters), exon shuffling (involved in the evolution of blood clotting factors) and the addition of transposable elements to coding sequences. Finally, and simplest of all, we have many examples of adaptive changes of protein sequence between closely related species, including differences in the coat colour of mice, the digestive enzymes of herbivores, and the haemoglobins of highaltitude birds and mammals.

In contrast, the evidence for the adaptive divergence of gene switches is still thin. The best case involves the loss of protective armour and spines in sticklebacks, both due to changes in regulatory elements. But these examples represent the loss of traits, rather than the origin of evolutionary novelties. Carroll also gives many cases of different expression patterns of Hox genes associated with the acquisition of new structures (such as limbs, insect wings and butterfly eyespots), but these observations are only correlations. One could even argue that they are trivial. Given the centrality of Hox genes in development, it is almost inevitable that such genes are involved in the evolution of a new trait. Carroll's correlations, however, do not compel us to believe that changes in these genes are the key factor in the evolution of such traits. We now know that Hox genes and other transcription factors have many roles besides inducing body pattern, and their overall function in development - let alone in evolution - remains murky.

In the end, we simply don't know the relative importance of protein and non-protein changes in creating biological diversity. In many cases, both must have evolved in tandem, as different members of gene families are often expressed in different tissues or at different times. For example, the protein sequence of fetal $\gamma$-haemoglobin evolved adaptively to wrest oxygen from the mother's blood, but its gene is turned off after birth, probably by new regulators. Carroll's emphasis on gene switches may prove correct, but this awaits the labours of the next generation of biologists.

Although Endless Forms Most Beautiful is a lucid and valuable summary of evo-devo, it does proclaim a clever but still unproved hypothesis as central to the evolutionary process. As Carroll himself notes: "Simplification may indeed be necessary for news articles, but it can distort the more complex and subtle realities of evolutionary patterns and mechanisms."

Jerry A. Coyne is in the Department of Ecology and Evolution, University of Chicago, Chicago, Illinois 60637, USA.

\title{
EXHIBITION
}

\section{Fresh flowers}

\section{A New Flowering: 1000 Years of \\ Botanical Art \\ At the Ashmolean Museum in Oxford, UK, until 11 September 2005. \\ www.ashmol.ox.ac.uk/ash/exhibitions/ exh075.html}

\section{Colin Martin}

Botanical artists face the dual challenge of capturing the essence of each plant species artistically, yet representing the plants and their stages of growth with absolute scientific

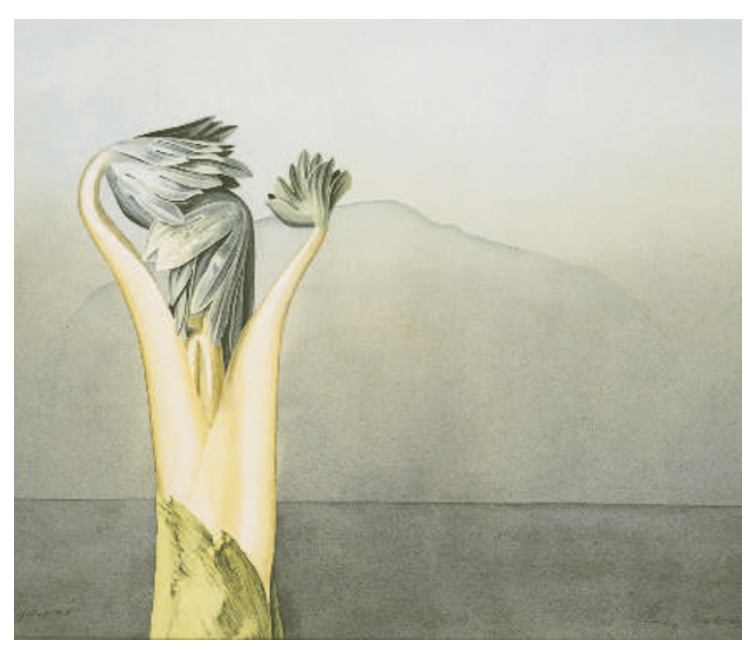

Setting the scene: the Scottish island of Ailsa Craig is the backdrop to Rory McEwen's painting of monk's hood. accuracy. The veracity of great botanical art derives from artists' skill at producing work that both records plant species in technical detail and heightens viewers' perception of the natural world.

The exhibition A New Flowering is a clever juxtaposition of examples of contemporary botanical art, selected from a private collection assembled since 1990, with rarely exhibited works from the past millennium, chosen from the collections of the Ashmolean Museum and several Oxford colleges. It highlights both the novelty of current practice in botanical art and its continuity with the past.

Historic works on show include eleventh-century herbals, which name and describe plants and list their properties and uses; fifteenthcentury illuminated manuscripts, whose borders are decorated with flowers; sixteenth-century printed books, illustrated with woodcuts; seventeenth-century books that are illustrated with engravings; and eighteenth- and nineteenthcentury works, notably some particularly sumptuous volumes that depict freshly discovered plant species. Throughout, contemporary botanical images are displayed alongside related earlier works. 
Two important twentieth-century botanical artists whose works are included in the exhibition expanded their influence beyond the world's herbaria into environmental conservation and modern art, respectively. English artist Margaret Mee moved to Brazil in the 1950s, where she made 15 expeditions into the
Amazon rainforest and became one of the first conservationists to raise concerns over its exploitation. And Scottish artist Rory McEwen, for whom the placement of flowers, vegetables and leaves in his pictures was as important as the plants themselves, propelled botanical art into modern art galleries, includ- ing the Museum of Modern Art in New York. His eerie 1977 watercolour of an unfolding young shoot of monk's hood (Aconitum) with a ghostly profile of the Scottish island Ailsa Craig in the background, shown on the opposite page, is particularly striking.

Colin Martin is a writer based in London.

\section{Flood warnings}

\section{The Future of Large Dams: Dealing with the Social, Environmental and Political Costs by Thayer Scudder \\ Earthscan: 2005. 432 pp. £45}

\section{Christer Nilsson}

During the past 50 years the world has experienced an unprecedented increase in the number of large dams, from 5,700 in 1950 to approximately 50,000 today. The International Commission on Large Dams defines a large dam as one spanning 15 metres or more from base to top, or storing more than 3 million cubic metres of water. Almost half of them are in China, but the United States, India, Spain and Japan also have large numbers. The peak years for dam building were the 1970s, but construction continues apace, especially in countries that were late to industrialize.

But how many large dams do we really want? Should old ones be decommissioned and plans for new ones halted because they cause serious, irreversible degradation of lifesupport systems? For example, dams can eliminate ecosystems and reduce biodiversity, fisheries and bioproduction. Or should we keep our dams because they provide necessary water and energy to populations that have grown beyond the carrying capacity of their environments? These are difficult political questions, and Thayer Scudder adds a human dimension that is surprisingly often ignored or inadequately understood in the planning and building of large dams. In The Future of Large Dams he speaks up for the millions of people who are directly affected by large dams and reservoirs, many of whom are "poor, uneducated, relatively powerless rural residents".

Scudder, an anthropologist at the California Institute of Technology, writes with great authority, having been one of the 12 commissioners of the World Commission on Dams. This role has given him a remarkable insight into the global politics of large dams and their social, economic and environmental consequences. His position on large dams has changed from strong support to anger and despair over the poor treatment of people who live near dams. He now believes that most of the really large dams impose unacceptable environmental and social costs.

Hundreds of millions of people are adversely affected by dams, but curiously no precise figures are available. At least 40-80

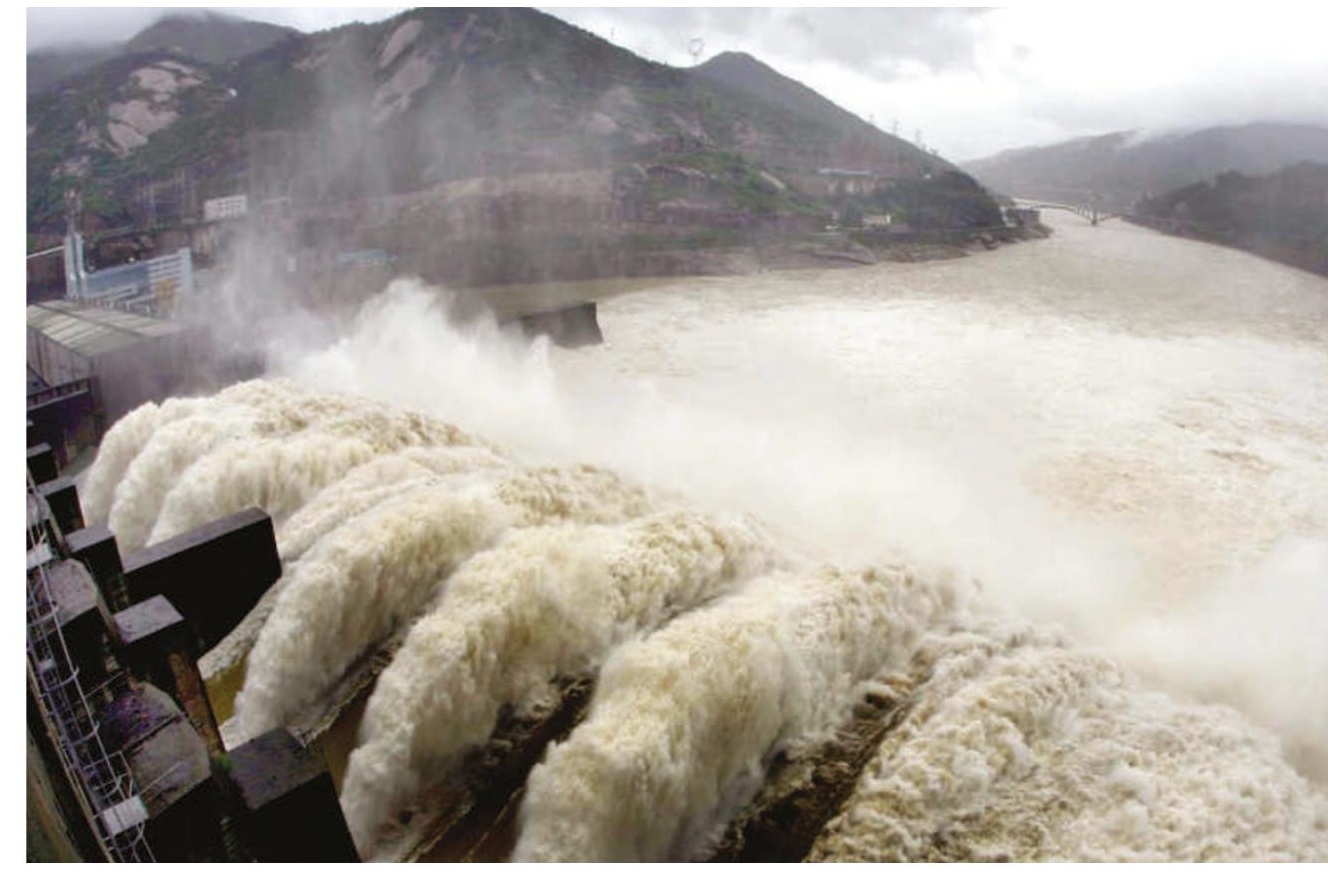

Water power: large dams such as China's Shuikou Dam can have a huge effect on local populations.

million people have been resettled from planned reservoir basins, and this evacuation also affects the populations who receive them. Additionally, the lifestyles of those living downstream of the dam are changed because the water flow is regulated. Scudder spends a large part of his book discussing the social complexities of these three groups of people.

He discusses the plight of people who have lived for generations close to a free-flowing river but who may suffer from shortage of food and water, or contact with new diseases, after relocation. People may be stressed by having to leave burial grounds or religiously important sites, and local leaders may be undermined whether they oppose resettlement or not. Scudder presents a new study on people whose parents were resettled, involving a total of nearly 1.5 million people affected by 50 different dams across the world. Their living standards improved in only $7 \%$ of cases but worsened in $70 \%$, with the rest having no significant change. Scudder also provides an in-depth analysis of a few major dam projects and discusses the institutions involved in the politics and economics of large dams. The book's personal tone makes it enjoyable to read, but this is also a scholarly book that has numerous footnotes and references.

The story that Scudder tells is rather depressing, but he does try to find a way forwards. In the final chapter, he lists seven sets of recommendations on how to make decisions about the possible construction of large dams in the future. These recommendations are derived from suggestions made by the World Commission on Dams and are expanded to take account of existing dams. They include more thorough investigations into the possible consequences of dams, improved stakeholder involvement, and an active search for alternative solutions to water-related problems.

Scudder concludes by stating that the application of his recommendations would considerably reduce the number of large dams being built. Sustainability should be a top priority, and the book is a valuable reminder of the dangers of destroying sustainable rural societies largely to support unsustainable cities or large industries. Hopefully, Scudder's book will help to lessen the damage caused by the building and maintenance of large dams. Christer Nilsson is in the Landscape Ecology Group, Department of Ecology and

Environmental Science, Umeå University, Umeå 90187 , Sweden. 